\title{
From fragmentation to imagination: moving to Marketing's next Era
}

\author{
Robin A. Coulter ${ }^{1}$
}

Received: 2 October 2016 / Accepted: 17 October 2016/Published online: 9 November 2016

(C) Academy of Marketing Science 2016

\section{From fragmentation to imagination: moving to Marketing's next Era}

Imagination is part of Jerry Zaltman's DNA. His "little" book, Theory Construction in Marketing: Some Thoughts on Thinking (Zaltman, LeMasters, and Heffring 1982), has had a "big" impact, inspiring many in our field to think broadly. Jerry's Association for Consumer Research (ACR) Presidential Address argued for serendipity and exploration of hidden events that "are the source of new concepts on which the continued growth of our field is so dependent" (Zaltman 1983, p. 1), and his ACR Fellow's Award speech encouraged us to "Think big and do it now...tackle problems or issues where new insights have the potential of changing (a) at least some thinking on the part of many people, or (b) a great deal of thinking on the part of some people" (Zaltman 1991, p. 8). In the early 1990s, Jerry Zaltman's imagination and questions about the ability of traditional research methodologies to unearth unique customer insights, as well as his reading in myriad fields of study (e.g., cognitive neuroscience, art therapy, and linguistics), led to the development of the Zaltman Metaphor Elicitation Technique (ZMET, Zaltman 1997; Zaltman and Coulter 1995). A decade later, Zaltman (2000) challenged consumer researchers to "take a hike" and broaden our intellectual peripheral vision; notably, this article coupled with his ZMET work, were among the first in the marketing discipline to draw attention to the unconscious as a key determinant of consumer behavior (see also Zaltman

Robin A. Coulter

robin.coulter@business.uconn.edu

1 School of Business, University of Connecticut, 2100 Hillside Road, Storrs, CT 06269-1041, USA
2003). Importantly, Jerry's engagement with thinking is marked by fun and playing with new ideas, as he calls it, workable wondering, "the exercise of practical yet innovative thinking, and viewing the worlds of theory and practice as mutual informing sides of the same coin" (Zaltman 2011, p. 336; Zaltman and Zaltman 2008).

Indeed, for many years, Zaltman has encouraged us as marketing scholars to have a healthy skepticism of habitual thinking, a contemplation of what something is and what it is not, and to get out of comfort zones. In his AMS Review paper, "Marketing's Forthcoming Age of Imagination," Zaltman (2016) speaks not only to an individual's imagination, but also and importantly, to imagination in the context of the marketing discipline. Specifically, he articulates four reasons that our discipline is poised to enter a more imaginative period: 1) technology and artificial intelligence advances expand our idea set, 2) the amount of information available to feed imagination is unparalleled, 3) marketing, as a business discipline, is uniquely poised to access developments in human sciences and technology, and 4) the field of marketing increasingly has outlets to publish ideas that would stimulate theory development and insights. Zaltman discusses imagination and its job to fill empty spaces, as well as ways to engage imagination and some of the challenges that marketing academics and practitioners face in developing and articulating new ideas for the discipline.

In this commentary, I bring Csikszentmihalyi's systems approach (2013) to address Zaltman's provocative statement, "The field has an opportunity to enter a more imaginative period" (2016). Specifically, Csikszentmihalyi (2013, p. 6, pp. 27-29) argues that creativity is the interaction of three elements: 1) a domain or culture (e.g., the marketing discipline) that contains a set of symbolic rules and procedures, 2) the field of experts (e.g., the collective marketing faculty, journal editors, reviewers, conference chairs) who act as 
gatekeepers for new ideas, theories, and methods, and 3) the individual person who brings novelty into the symbolic domain. With this backdrop, I begin with an overview of the evolution of the marketing discipline, drawing attention to the current "Age of Fragmentation," and articulating challenges that we face in moving to an "Age of Imagination." Next, I share actionable plans for countering some of the roadblocks posed to better facilitate a more imaginative era. Finally, I focus on how we, as individual contributors to marketing, can shape our own awareness and imaginative thinking to advance our discipline beyond fragmentation to imagination. There is work to be done, but there is great promise of a forthcoming "Age of Imagination" for the discipline.

\section{The evolving discipline of marketing}

Four decades ago, Hunt declared, "No matter which definition of marketing one prefers, the scope of marketing is unquestionably broad" (1976, p. 16). Today, the scope of marketing is unquestionably broader! Since 1976, marketing scholars have tackled myriad research questions focused on consumers, organizations, and society with an increasing number of methods: surveys, lab and field experiments, netnographies, depth interviews, large datasets, and brain imaging. This expanse is evident in the changed definition of marketing, as well as the proliferation of academic journals and marketing-related organizations. In the following paragraphs, I share a brief history of marketing to frame the expansion of the discipline.

Marketing, as an academic discipline, began in the early 1900 s in a select few U.S. universities, and the first official definition of marketing, adopted in 1935 by the National Association of Marketing Teachers (NAMT), read: "Marketing is the performance of business activities that directs the flow of goods and services from producers to consumers." NAMT and the American Marketing Society (AMS), comprised of researchers and practitioners, collaborated to form the American Marketing Association, which has been responsible for the "official" definition of marketing since 1948. The definition (see Fig. 1) was revised in 1985, 2004, and then again in 2007 as a consequence of significant criticism from the academic community for the 2004 definition's neglect of the role of marketing in creating value for society at large (Gundlach 2007; Hunt 2007; Lusch 2007; Mick 2007; Ringold and Weitz 2007; Shultz 2007; Sheth and Uslay 2007; Wilkie and Moore 2007). The 2007 definition remains in place today, "Marketing is the activity, set of institutions, and processes for creating, communicating, delivering, and exchanging offerings that have value for customers, clients, partners, and society at large." Undeniably, the scope of marketing is broad, focused on micro-level individual customer concepts, attitudes, goals, and behaviors, the mezzo-level organizations and their practices and interplay with customers and stakeholders, and the macro-level activities related to society at large.

As the discipline of marketing has expanded, so has the number of marketing-related journals. Journal of Retailing originated in 1925, followed by Journal of Marketing in 1936. Over the past eighty years, we have witnessed the launch of many outlets to disseminate marketing scholarship. Baumgartner and Pieters (2003) identify upwards of 50 journals with a marketing focus. Lehmann (2005, Table 1, pp. 138-140) takes an even broader brush identifying over 100 marketing-related journals, with major classifications as: "Marketing in General" (8), "Quantitative Marketing Methods and Science" (11), "Consumer Behavior" (11), "Direct Marketing and e-commerce" (9), "Channels and Sales" (7), and "Social Issues and Public Policy" (6); other journals have a substantive niche or specific industry focus. The list of journals has continued to grow, with the 2011 launch of AMS Review and the 2015 launch of the Journal of the Association for Consumer Research. Over the past four decades, an increasing number of business schools have pointed to publications in the four "A," "major," or "premier" journals (Journal of Marketing, Journal of Marketing Research, Journal of Consumer Research, and Marketing Science) as the currency necessary for merit-based compensation and the award of promotion and tenure. Figure 2 illustrates a sampling of the journals originating over time, and even this admittedly small subset of the journals represents the diversity of research topics of interest to marketing scholars today. Further, since

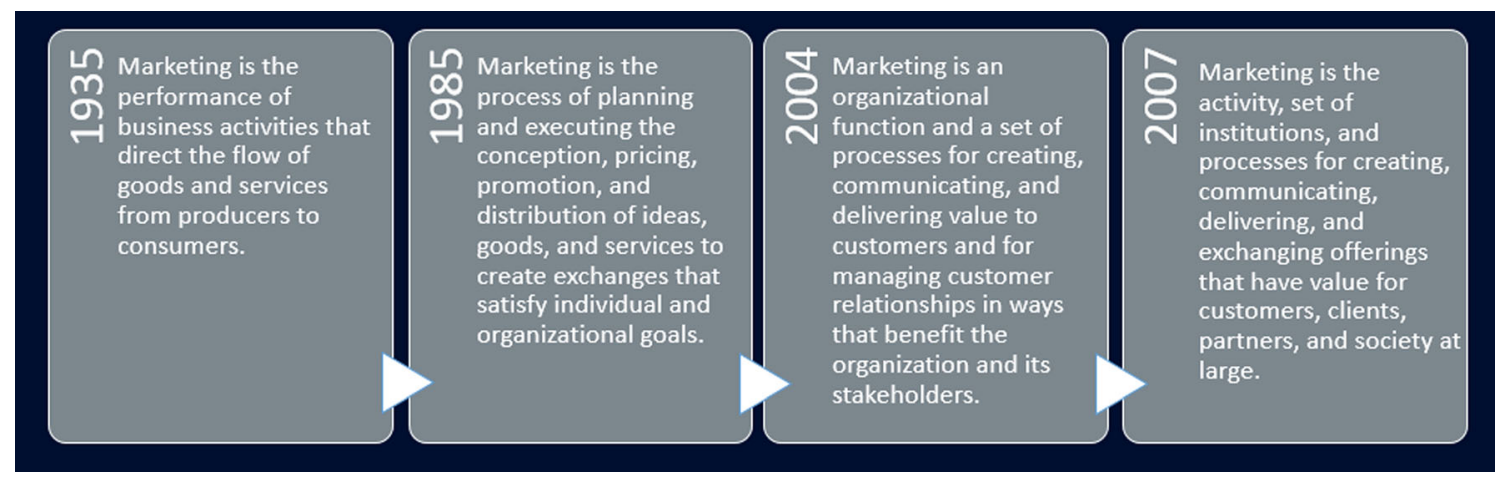

Fig. 1 The Evolution of the American Marketing Association Definition of Marketing 
Fig. 2 A Sampling of MarketingRelated Journals

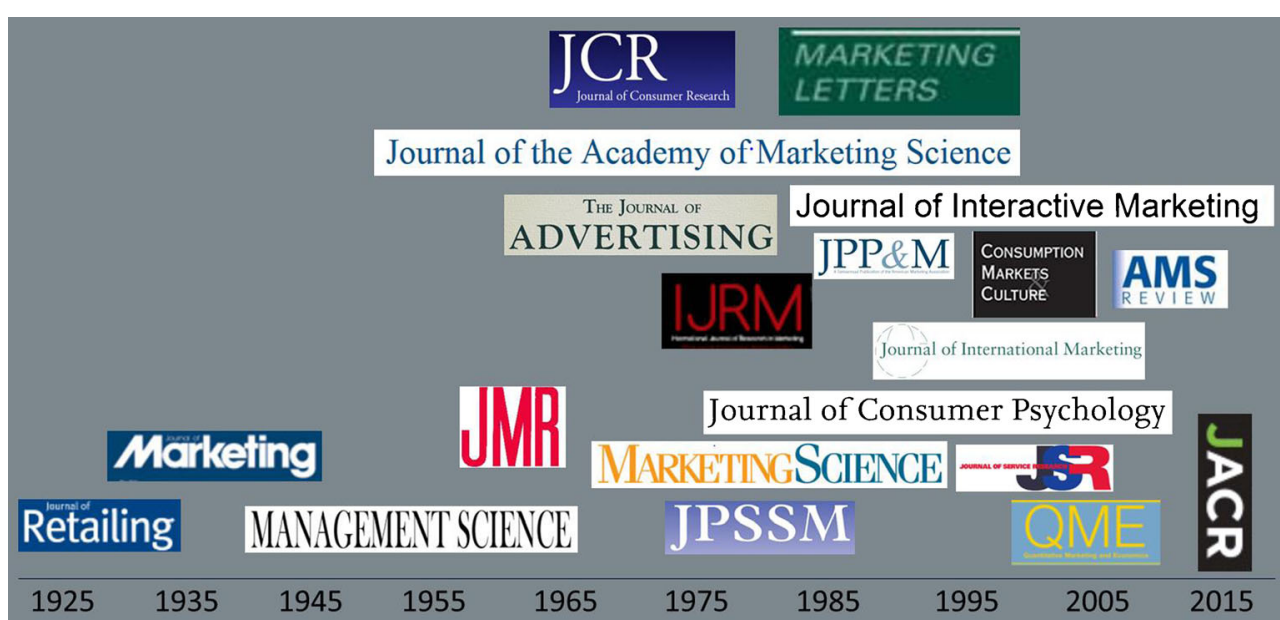

the turn of the twentieth century, marketing has welcomed numerous organizations focused on topics, including general marketing strategy and management, mathematical modeling, research methods, consumer research, and public policy (Lehmann 2005).

One could argue that an expanded scope of marketing is a benefit to the discipline. We have more sandboxes for marketing scholars to play in, and the discipline can cover and "own" more intellectual space. But, Csikszentmihalyi (2013, p. 9) foreshadows, “....as culture evolves, specialized knowledge will be favored over more generalized knowledge," and acknowledges, "this trend toward specialization in not necessarily a good thing...[it] can lead to cultural fragmentation." How has this specialization impacted the marketing discipline? Indeed, Wilkie and Moore (2003) argue convincingly that marketing has landed in an "Age of Fragmentation," specifically marked by the positivist-post-positivist debate and schism within consumer behavior, the development of more complex methodologies and analytical techniques, and an increased attention by universities to publishing in the "major" journals as the path to tenure. They lament (p. 135), "fewer academics are interested in making the effort to pursue the entire mainstream of marketing thought: Instead specialization has come to play the primary role in our professional lives."

This "Age of Fragmentation" has had numerous deleterious effects for the discipline, including: 1) an increasing focus on methods and methodological rigor, 2) less attention to conceptual thinking and theory development, 3 ) a partitioning of scholars into methodologically defined groups, 4) less accessible research to other academics and practitioners, and 5) ultimately, increased marginalization of marketing (Lehmann 2005; MacInnis 2005, 2011; McAlister 2005; Reibstein, Day, and Wind 2009; Sheth and Sisodia 2005; Wilkie 2005; Wilkie and Moore 2003; Yadav 2010; Zaltman 2016). Reibstein, Day, and Wind (2009, pp. 1-2) express concern, "The prevailing research paradigm in most parts of marketing academia is to begin with a new methodology, dataset, or a behavioral hypothesis and only then occasionally ask where it might be applied... The resultant conclusions are of some relevance to other researchers, but they offer little guidance for marketing decision making."

This "Age of Fragmentation" with increasing insularity begs the question of relevance and impact of the marketing discipline. Sheth and Sisodia (2005, pp. 10-11) reporting on a day-long symposium "Does Marketing Need Reforms?" submit that "marketing academics and practitioners alike are suffering from 'marketer myopia;' that is they are so focused on what they do that they fail to notice significant changes in the environment around them." They share that other senior leaders express concern about the discipline becoming too self-centered and isolated (Yoram Wind) and too data driven (Frederick Webster). More recently, Lehmann, McAlister, and Staelin (2011, p. 155) concur, "This growing complexity of research and fragmentation of the field increases the likelihood that any given piece of academic research in marketing speaks only to a limited set of marketing academics. It also implies that the research is less likely to examine issues that span boundaries."

As we contemplate a future for the marketing discipline, it is critical that senior scholars, with attention to younger colleagues and doctoral students, attend to traversing the divides, building bridges across the schisms, and promoting a stronger sense of the "collective self" for the marketing discipline. In the absence of this effort, we jeopardize further fragmentation, and our ability to successfully pursue an "Age of Imagination."

\section{Observations and actionable advice from the field}

Many respected thought leaders in marketing have reflected on the traps and roadblocks inherent in this "Age of Fragmentation." Herein, I offer "action plans" related to the discipline's culture and mandates, drawing upon the work of leading scholars, that will support a move of marketing into an "Age of Imagination." I pay special attention to marketing doctoral students and younger scholars in order to broaden their appreciation of the breadth and interrelatedness of marketing. 
Action plan 1 - "drop labels, de-camp, lose the comfort zone"

Over the past several decades, we have become accustomed to compartmentalizing and labeling our faculty and doctoral students as strategy, modeling, consumer behavior, and policy, and/or by their specific methodological focus, be that, for example, experimentalist, game theorist, or empirical modeler. Reibstein, Day, and Wind (2009, p. 3), with regard to doctoral candidates, observe that they "must declare which track they are in, behavioral or quantitative, not the substantive issues they are addressing." With specific attention to a focus on the methodological labels, MacInnis (2005, p. 14-15) recounts numerous adverse effects, including: 1 ) an overemphasis on empirical work versus tackling conceptual work and provocative questions, 2) the formation of "camps" around methods and resultant increased group think and reduced divergent perspectives, and 3) a reduced likelihood of bringing multiple methodologies to address interesting questions (see also MacInnis 2011; Yadav 2010). Moorman (2016, p. 563), calls the quant, $\mathrm{CB}$, and managerial labels divisive, and encourages a more tolerant and inviting stance, "If marketing is going to thrive as a field, seeking out [substantive areas] and reaching across to chat and work with scholars across the discipline is important." Russ Winer (2016) in his 2016 AMA-Sheth Foundation Doctoral Consortium plenary talk, "Marketing Silos," discussed concerns that our journals are more narrowly focused, our doctoral students are coming out of their programs more narrowly trained, and our rookie faculty recruiting process categorizes students as behavioral, quant, and strategy. He argues that these factors are restricting the scope of research inquiry and research partnerships that could produce exciting interdisciplinary findings.

Directing attention to substantive research questions of interest to marketing is critical to dropping methodological labels and "de-camping" the discipline. We need to supplant the specialized, parochial, and insular lens with a broadened appreciation and tolerance of the various epistemologies and methodologies. Particularly as related to the methodologybased "camps," as a discipline, we would do well to appreciate that "all methods of inquiry are compromises with reality" (Zaltman 2011, p. 342). One of my favorite articles, "Dilemmatics: The Study of Research Choices and Dilemmas" (McGrath 1981), though admittedly dated (relative to newer methodologies), points to the flaws of each type of method and the tradeoffs that a researcher must consider when choosing one method over another. Another way to look at this article is to think about how to combine different methodologies to bring different lenses to address the research question. With attention to broadening the current specialization of courses and content for doctoral students, Russ Winer (2016) submits that doctoral students should be advised to take courses and explore areas outside of his/her main field of study, which would have very positive long-term implications for the discipline. Other venues provide opportunities for de-camping and expanding comfort zones. For example, the 2016 AMA-Sheth Foundation Doctoral Consortium hosted by University of Notre Dame brought a substantive research question focus to the programming, with attention to exposing doctoral students to the breadth of marketing; further, conferences address a wide range of topics and attending sessions outside of our comfort zones would result in different sources of inspiration.

\section{Action plan 2 - "embrace theory development"}

Developing theory is central to the viability of our discipline. As Zaltman (2016) states, "The attention given to theory construction - marketing's space probes - is one barometer of imagination's health in academia." Indeed, Zaltman $(1983,2016)$ and many scholars have called for increased attention to theory development generally, but also with particular attention to doctoral student training, and publishing of conceptual articles (Kohli 2009; MacInnis 2011; Monroe 1993; Olson 1982; Price 2014; Yadav 2010; Zaltman, LeMasters, and Heffring 1982). Notably, Wilkie and Moore (2003) document the identification of a significant number of new constructs and theories from 1952 to 1977, followed by a significant decline. More recently, Yadav (2010) and Rapp and Hill (2015) also report on a paucity of conceptual pieces in the four major marketing journals. This imbalance between conceptualization and empirical articles has had noticeably deleterious consequences. Several scholars rebuke the discipline and leading journals for increasingly being concerned about "black-belt methods" and execution at the expense of theory and ideas (Kohli 2009; Lehmann 2005; Lehmann, McAlister, and Staelin 2011; MacInnis 2011; McAlister 2005; Yadav 2010). Additionally, the decline of conceptual articles means that the discipline is likely missing opportunities to advance and debate provocative research questions. Notably, two journals, Review of Marketing Research and AMS Review, have a particular commitment to conceptual articles (see also Yadav 2010).

As a faculty member at Northwestern, Pittsburgh, and Harvard, Zaltman infused doctoral programs and inspired students with the importance of big ideas and theory construction as critical to knowledge creation. Zaltman (2016) raises questions about doctoral programs and imagination related to the time spent on addressing the general importance of theory, as well as dedicated time spent on theory construction during course work and in the context of the dissertation, with a call to curriculum reform. Others support his contentions, MacInnis (2011, p. 152) shares her concerns that in most doctoral programs new students are "immediately 'indoctrinated' to learn a prevailing paradigm" and as such, we are likely to be "silencing new ways of thinking." She argues for attention to strengthening 
conceptual and theory building skills so that they can be more imaginative in their thinking. In a similar vein, Yadav (2010, p. 12) calls for a restoration of "pedagogical balance among the substantive, conceptual, and methodological domains of the discipline" with regard to doctoral programs; Pham agrees (2013), "Our doctoral curriculum should reflect a broader range of theoretical perspectives and promote a deeper grounding of our teachings in actual consumption behavior and its substantive implications." In an attempt to fill this void within marketing department Ph.D. curricula, Kohli, Yadav, MacInnis, and Jaworski (Kohli et al. 2016a, b), three of whom were doctoral students at the University of Pittsburgh while Zaltman was on faculty, offered very well-received sessions on theory construction at the Winter 2016 and Summer 2016 American Marketing Association Conferences.

\section{Action plan 3 - "choose relevance"}

As noted, in thinking about marketing problems, Zaltman (1991, 2016) advises us to ask, "How much thinking on the part of how many people will be affected by this research?" to gauge importance. A lot of thinking by a few people or a little thinking by many people is the litmus test for relevance. In moving toward an "Age of Imagination," choosing topics that build theory, addressing questions of relevance to consumers, managers, and policy makers, and providing guidance to marketing decision making in a global world is critical. Lehmann, McAlister, and Staelin (2011) suggest that the need for analytical rigor and focus of methods in academic journals has surpassed the need for "relevance, communicability, and simplicity...to the detriment of the field of marketing." Around corners and over coffee at conferences and in hallways, there is a sentiment that we, as a discipline, are researching smaller and smaller problems that are of less and less consequence. Reibstein, Day, and Wind (2009) call for an outward-looking mindset with attention to issues of strategic import, including: major societal concerns, achieving profitable growth for the firm, assessment of marketing's role within the firm, and a marketplace in which we see an increasing presence of new media and channels, global markets, and empowered consumers. They also recommend bringing issues of business to doctoral programs, so that students have a relevant context for their research.

Certainly, there are expectations that marketing academics and their knowledge creation will impact marketing practitioners, consumers, and policy makers. In this "Age of Fragmentation," Reibstein, Day, and Wind (2009) pose the question, "Is Marketing Academia Losing Its Way?" and becoming more insular rather than examining issues of relevance to firms, customers, policy makers. Kerin (2005) and Brown (2005) look to have more relevance in marketing practice. Upon becoming editors of Journal of Consumer Research, Dahl, Fischer, Johar, and Morwitz (Dahl et al. 2014, p. iii) committed to "meaningful consumer research," with attention to relevance of work to not only fellow academics, but also to "public policy makers, marketing managers, environmental activists, or aspiring entrepreneurs." Importantly, Wilkie and Moore $(1999,2003)$ and others have reminded us of the relevance and obligation of marketing for society and societyrelated issues. David Mick has had a clear voice in this agenda; his ACR Presidential Address (Mick 2006) called for consumer researchers to "raise the meaning and mattering of our scholarship" to help consumers to transform their lives, and his fortitude set in motion work around Transformative Consumer Research. More recent efforts include the 2017 Winter AMA Conference "Marketing for a Better World," co-chaired by Rajesh Chandy, Chris Moorman, and Jeff Inman, to bring attention to and raise the consciousness of the discipline to address questions of relevance to the field and the world.

\section{Action plan 4 - "champion big ideas, be respectful, practice tolerance"}

In transporting the discipline to an "Age of Imagination," it is perhaps big ideas, respect for others, and tolerance of others' ideas that serve as the connective tissue among the first three action plans. Our journals are the key means of knowledge dissemination of big ideas, and acknowledging their role in pursing imaginative thinking is critical. Price $(2014$, p. 1) speculates that our discipline does "a better job of teaching doctoral students how to publish articles and get tenure than we do of giving our students 'the deep principles of science and the love of it, what's behind it and why it's worth doing" (Feynman 1988, p. 14). Pham (2013) admonishes the reward structure, "as long as researchers are rewarded mostly for maximizing the number of articles they publish in A-level journals...then the narrow scope, narrow lenses, narrow epistemology, disregard for content, overgeneralizations, research by convenience, and 'theories of studies, will remain prevalent in our field." McAlister (2005) also warns us that opportunities to publish in the major journals are increasingly limited, as the overall number of marketing faculty and doctoral students within and outside the U.S. who are competing for journal space has increased dramatically. Questions abound about whether this attention to a few key journals for the field is a positive or negative in the face of continuing growth and fragmentation (Wilkie 2005), whether tenure clocks should be extended (Wilkie 2005), whether a post-doctoral infrastructure should be considered (Staelin 2005b), and whether more pages should be added to the major journals (McAlister 2005).

Journal editors and reviewers have vital roles in shaping the scope of work in the discipline, and ensuring that big ideas get traction. Staelin (2005a) recounts two important editor decisions that changed conversations about work in marketing: Ruth Bolton's decision, as editor of $J M$, to dedicate journal 
pages to cover customer relationship management, and Rich Lutz's action, as editor of JCR, to give a voice to interpretive researchers. Lehmann, McAlister, and Staelin (2011) argue for editors to have a broader vision, to not get caught in reviewers' narrow lenses; they encourage a rebalancing of review criteria with an eye to addressing two questions: (1) Is this work interesting? and (2) Is it not wrong? Kohli (2009) and Moorman (2016) concur, suggesting that reviewers not forsake good ideas because they do not like the execution. As part of this broad action plan, MacInnis (2003, p. 344) importantly reminds us as reviewers that the goal is "to advance the science and practice of marketing, not preserve the status quo," and during the process to be kind and constructive in sharing expertise.

\section{Taking action}

Is it possible for the marketing discipline to progress to an "Age of Imagination"? As Csikszentmihalyi (2013, p. 28) cautions, "a domain cannot be changed without the explicit and implicit consent of a field responsible for it." We have acknowledged the institutional barriers and expressed strong concern about fragmentation. Inertia, however, is easy. Despite articles and commentaries appearing in marketing journals articulating the detrimental effects of fragmentation, these "paper" voices have not moved the needle in terms of doctoral program curricula, journal content and review processes, theory construction, and use of multiple methods to address the pressing issues and questions. Staelin (2005a, p. 22) provides a powerful argument for attention to the scope of marketing (in addition to a specialization) to acquire an understanding of the diverse approaches in our field so as to respect others' work, and "to understand how our field is integrated into the broader discipline of business. Without respect and this broader knowledge, there is less of a chance that [younger marketing scholars] will be able to solve the next set of big problems facing our profession." Perhaps a mandate is in order, perhaps it is time to create a "Marketing's Age of Imagination" Task Force with visionaries and scholars who are creative, curious and imaginative, who have a vision for a discipline that is marked by mutual respect across conceptual, substantive, and methodological domains, and who are committed to a discipline that makes "big" contributions to marketing thought that impact the practices of students, consumers, firms, and society at large.

\section{Fostering a culture of imagination in marketing academics}

And now, to each of us, as individuals, who are tasked with bringing our imagination to marketing. Imagination, "the process of generating missing ideas by drawing upon and then going beyond what is known," is "the connective tissue between data and meaning" (Zaltman 2016). Zaltman suggests that imagination is inextricably related to curiosity, creativity, and originality. Specifically, he discusses curiosity as the desire to learn or know something more about something, and acknowledges that "we can arrange our lives to stoke our curiosity or quash it" (Leslie 2014, p. xix). Zaltman (2016) further suggests that creativity "is best viewed as the pragmatic branch of imagination," emphasizing originality ("the degree to which a blank space is filled with a solution that is different from accepted practices") and appropriateness ("how on-strategy or goal-oriented the solution is"). Csikszentmihalyi (2013, p. 28) identifies a creative person as "someone whose thoughts or actions change a domain, or establish a new domain."

\section{The goods for imaginative thinking}

Recent developments in neuroscience and psychology document that creative and imaginative people have "messy minds" and that much of what we imagine and create is born of a complex interplay between the conscious and the unconscious (Boden 2013; Bressler and Menon 2010; Buckner 2012; Custers and Aarts 2010; Dijksterhuis and Meurs 2006; Edelman and Tononi 2000; Grant 2016; Kaufman and Gregoire 2015; Mlodinow 2012; Zaltman 2016). Three findings are particularly relevant to engaging in imaginative thinking to address big questions and build theory in marketing.

First, at least three networks are critical to imagination: the execution network, the default (or imagination) network, and the salience network (Bressler and Menon 2010; Beaty et al. 2014). The execution network ensures attention and goal focused planning and engagement, whereas the default (imagination) network is not particularly active related to daily life. Thus, the former is the "on task" network that helps to focus imagination; the latter is the "at rest" or "drifting" mind that engages many regions of the brain to "construct personal meaning from our experiences, remember the past, think about the future, imagine other perspectives and scenarios, comprehend stories, and reflect on mental and emotional states - both our own and those of others" (Kaufman and Gregoire 2015, p. xxviii). The salience network facilitates motivation. Taken together, these networks are critical for thought and imagination.

Second, work in neuroscience suggests that coming up with a new idea can happen via one of three types of psychological processes (Boden 2013). Combinational creativity occurs when an individual makes connections between ideas that are currently in his brain to come up with a new idea; exploratory creativity is also grounded in ideas that are currently in the brain, but curiosity yields ideas that go beyond simply combining existing ideas. The most radically different ideas 
come from transformational creativity, as it involves the breaking from or ignoring culturally sanctioned norms. Boden reports that transformational creativity is rare, that most scientists and artists create close to home rather than in unfamiliar territory.

Third, when considering imagination, insight is another relevant construct. Kounios and Beeman (2014) define insight as "any sudden comprehension, realization, or problem solution that involves a reorganization of the elements of a person's mental representation of a stimulus, situation, or event to yield a nonobvious or nondominant interpretation." Kounios and Beeman (2009) also note that although insight is sudden, there is significant unconscious processing occurring prior to the "aha" moment. Further, neuroimaging and electrophysiological studies indicate that insight is associated with increased neural activity in the right cerebral hemisphere of the brain. Similar to creativity, insight is linked to restingstate neural activity.

As we reflect on bringing imagination to fill empty spaces posed by marketing questions, this neuroscience research warrants attention. Notably (and perhaps not surprisingly), our imagination works best when we are not fully engaged with the details of daily life. Imagination, particularly as applied to new and big ideas, requires a quiet of the mind, a dedication to workable wondering, a patience with incubation and contemplation. Imagination is a mixture of wisdom and imaginative play; it not only makes associations, but goes beyond mere associations. Transforming an idea into a manuscript involves theory development and testing; manuscripts are created by an ebb and flow of ideas, theories, and/or empirics. In the context of our development and dissemination of marketing knowledge, this research in neuroscience is significant in that making "quiet" time is a necessary condition for imaginative thinking.

\section{Imaginative thinking in marketing}

With attention to imaginative thinking in marketing, Zaltman (2016) discusses the complexity of imagination as "a fusion of culture, history, social context, cognitive dynamics, and personal idiosyncrasy." Given this backdrop and drawing upon research on creativity, originality, and insight, I share the following thoughts, particularly for doctoral students, as guides to engaging in the grand adventure of transforming marketing to an "Age of Imagination."

\section{Appreciate and leverage all of marketing and related do-} mains As noted, there has been a trend to building a depth (versus breadth) of understanding of marketing concepts and methods in doctoral training over the past decade. This approach has the advantage of doctoral students working in a particular domain space with attention to producing more journal submissions; the downside, however, is a narrow and limited perspective on the scope of marketing at a time when the scope of marketing has broadened extensively. In bringing imaginative thinking to the discipline, one needs a grounding in the base knowledge; as well as an understanding of the rules, the content of the domain, and the criteria of selecting new ideas (Csikszentmihalyi 2013; Kaufman and Gregoire 2015). In moving to a more imaginative era, marketing scholars would do well to: further understand the history and scope of the field, draw from multi-disciplinary (e.g., economics, psychology, anthropology) perspectives, work to develop theoretical perspectives, and at a minimum, appreciate "unfamiliar" methods and analytical techniques.

Bring passion and curiosity to explore provocative questions Provocative questions in marketing can be found by attending to what is happening in different consumption and managerial contexts, by reading academic articles or popular press, by observing consumers, managers, firms, and society "in action," by exploring thick and big data, and by examining established assumptions or yet to be stated boundary conditions. "To do research that matters begins first and foremost with doing research that matters to you - that addresses your own mysteries and burning questions!" (Price 2014). Torrance (1983) argues that having passion, falling in love with something, is key to creative energy, and Kaufman and Gregoire (2015, p. 82) stress, "cultivating a mind-set that is open and explorative might be the best thing we can do for our creative work." On the flip side of passion, Csikszentmihalyi (2013) reminds us that creative individuals temper their passion with objectivity. Indeed, work on being imaginative envisages the many possibilities for addressing meaningful issues of theoretical and practical relevance in marketing (Csikszentmihalyi 2013; St-Louis and Vallerand 2015).

Engage in imaginative play and workable wondering We live in an "always-on" world, and as the cognitive neuroscience research documents, it is critical to make time and space for imaginative thinking. Several of Csikszentmihalyi's dialectic tensions related to creative thinkers (2013) resonate here: traditional yet rebellious; wise with childish naiveté; playful yet disciplined; imaginative but rooted in reality. Other work reinforces that imaginative play is tied to creativity (Russ 2014; Russ and Zyga 2016), and the importance of a balance of mindfulness (a focused, nonjudgmental awareness of the present moment) and mind wondering (Kaufman and Gregoire 2015). As we avail ourselves to imaginative thinking "the goal is to be fully present to thoughts as they arise and to be able to switch flexibly between idle mind wandering and outward-focused attention" (Kaufman and Gregoire 2015, pp. 116-117). As Zaltman (2016) argues, being imaginative requires "a willingness to theorize about what might belong in [knowledge voids]." A more imaginative era of marketing will require that as marketing scholars, we actively set aside 
time and space for big ideas to germinate, percolate, and become fully baked; that we allow for the mindfulness and mind wandering to work together to produce ideas that are unique and thought provoking to address questions of relevance to consumers, firms, and society.

\section{Value the outsider's mindset for constructive creation} Zaltman (2016) cautions, "a barrier to imaginative thinking arises when like-minded people collaborate and inadvertently exclude diverse viewpoints." In the process of developing ideas and working on research, it is interesting to ask the question, "Whose opinion matters?" At the idea generation and refinement stage, Linda Price (2004), with consumer research interest, advocates for testing ideas at a cocktail party or with a cab driver, to get the reactions from the man/woman on the street. Her advice is well-taken and echoed by others investigating problems of managers and policy makers - speak to the audience you are studying (Brown 2005; Raju 2005; Webster 2005). Because journals serve as the clearing house for our imagination, is it also useful to ask peers to offer constructive comments before pressing the submit button (Grant 2016; Kaufman and Gregoire 2015). Then, navigating the review process requires a delicate balance of being open to ideas and criticism, to positively shape your work, but also a consciousness of your story to tell and defend. Zaltman (1991, p. 9) advises, "You will be tempted by reviewer advice and advice from senior colleagues... use criticism as a creative tool," and "have the courage of your convictions" to tell your own story (MacInnis 2011; Price 2014).

\section{A call to collective action: creating a culture of imagination in marketing}

The marketing discipline appears to be at a crossroads, with roadblocks from the "Age of Fragmentation" poised to hinder progress to a more imaginative era. Methodological silos have rendered an intolerance for work not squarely in one's methodological wheelhouse, created boundaries that have jeopardized progress on theory development, and resulted in insularity and narrow-mindedness that have precluded collaborative work across methods to develop innovative solutions to substantive marketing problems. Indeed, the "Age of Fragmentation" is characterized by camps having very different worldviews of what constitutes marketing thought and which research actually contributes to marketing knowledge. Embarking on an "Age of Imagination" requires a paradigm shift with attention to a common agenda of creating marketing knowledge, regardless of the method brought to bear on the research question.

In calling for a cultural shift in the discipline, I am reminded of Zaltman's ACR Fellow Address (1991) where he shared seven "basic principles" for doing research in marketing: Think big and do it now, not later; Think fun; Have the courage of your convictions when they are felt strongly; Use criticism as a creative tool; Challenge established assumptions; Have confidence and dedication; Develop wide cognitive peripheral vision; and Creatively bend the aforementioned to reflect your individuality. Institutionally, these principles characterized the Marketing Department at the University of Pittsburgh where I was a doctoral student during Jerry's tenure. Jerry set a tone for an intellectual atmosphere that appreciated, encouraged, and spawned a diversity of thought. His love of ideas (or ideaRs, as he would say) was coupled with thoughtful consideration, his wisdom juxtapositioned against a naiveté $\sim$ all of which made for an enriching and inspiring experience that cultivated an open-mindedness about how to engage in research and make contributions to the discipline. Based on recent communications with Jerry's colleagues and doctoral students at Northwestern (1968-1975), Pittsburgh (1975-1991), and Harvard (1991-2003), it is clear that Jerry's gift to our imaginations has had a profound effect on our lives, our thinking, and our collective agenda to engage all marketing scholars to contribute to the broad scope of our discipline. Jerry's call for a "Forthcoming Era of Imagination" should spur a commitment across the discipline, within Marketing departments, among faculty and doctoral students, to understand and appreciate $\sim$ neither silo nor denigrate $\sim$ imaginative contributions to marketing knowledge.

\section{References}

Baumgartner, H., \& Pieters, R. (2003). The structural influence of marketing journals: a citation analysis of the discipline and its subareas over time. Journal of Marketing, 67(2), 123-139.

Beaty, R. E., Benedek, M., Wilkins, R. W., Jauk, E., Fink, A., Silvia, P. J., Hodges, D. A., Koschutnig, K., \& Neubauer, A. C. (2014). Creativity and the default network: a functional connectivity analysis of the creative brain at rest. Neuropsychologia, 64, 92-98.

Boden, M. A. (2013). Creativity as a neuroscientific mystery. In O. Vartanian, A. S. Bristol, \& J. C. Kaufman (Eds.), Neuroscience of creativity. Cambridge: MIT Press.

Bressler, S. L., \& Menon, V. (2010). Large-scale brain networks in cognition: emerging methods and principles. Trends in Cognitive Science, 14(6), 277-290.

Brown, S. (2005). When executives speak, we should listen and act differently. Journal of Marketing, 69(4), 1-4.

Buckner, R. L. (2012). The serendipitous discovery of the brain's default network. NeuroImage, 62(2), 1137-1145.

Csikszentmihalyi, M. (2013). Creativity. Cambridge: Cambridge University Press.

Custers, R., \& Aarts, H. (2010). The unconscious will: How the pursuit of goals operates outside of conscious awareness. Science, 329(2), 47 50 .

Dahl, D., Fischer, E., Johar, G., \& Morwitz, V. (2014). Meaningful consumer research. Journal of Consumer Research, 41(1), iii-v. 
Dijksterhuis, A., \& Meurs, T. (2006). Where creativity resides: the generative power of unconscious thought. Consciousness and Cognition, 15, 136-146.

Edelman, G. M., \& Tononi, G. (2000). A universe of consciousness: How matter becomes imagination. New York: Basic Books.

Feynman, R. P. (1988). What do you care what other people think? New York: W.W. Norton and Company.

Grant, A. (2016). Originals: How non-conformists move the world. NY: Viking.

Gundlach, G. T. (2007). The American Marketing Association's 2004 definition of marketing: perspectives on its implications for scholarship and the role and responsibility of marketing in society. Journal of Marketing \& Public Policy, 26(2), 243-250.

Hunt, S. D. (2007). A responsibilities framework for marketing as a professional discipline. Journal of Marketing \& Public Policy, 26(2), 277-283.

Kaufman, S. B., \& Gregoire, C. (2015). Wired to create: Unraveling the mysteries of the creative mind. New York: Perigee.

Kohli, A. (2009). From the editor. Journal of Marketing, 73(1), 1-2.

Kohli, A., Jaworski, B., MacInnis, D., \& Yadav, M. (2016a), Special session: Theory construction workshop: Developing new theories using different approaches, and getting them published. Winter 2016 American Marketing Association Conference, February 27.

Kohli, A., Yadav, M., Jaworski, B., \& MacInnis, D. (2016b), Preconference session: The tradecraft of theory construction: A workshop. Summer 2016 American Marketing Association Conference, August 5.

Kounios, J., \& Beeman, M. (2009). The aha! moment: the cognitive neuroscience of insight. Current Directions in Psychological Science, 8(4), 210-216.

Kounios, J., \& Beeman, M. (2014). The cognitive neuroscience of insight. Annual Review of Psychology, 65, 71-93.

Lehmann, D. R. (2005). Journal evolution and the development of marketing. Journal of Public Policy \& Marketing, 24(1), 137-142.

Lehmann, D. R., L. McAlister, and R. Staelin (2011), Sophistication in research in marketing, Journal of Marketing, 75(July), 155-165.

Leslie, I. (2014). Curious: The desire to know and why your future depends on it. New York: Basic Books.

Lusch, R. F. (2007). Marketing's evolving identity: defining our future. Journal of Marketing \& Public Policy, 26(2), 261-268.

MacInnis, D. J. (2003). Responsibilities of a good reviewer: lessons learned from kindergarten. Journal of the Academy of Marketing Science, 31(3), 344-345.

MacInnis, D. J. (2005). Them versus us: woes on the bifurcation of the academic marketing discipline. Journal of Marketing, 69(4), 14-16.

MacInnis, D. J. (2011). A framework for conceptual contributions in marketing. Journal of Marketing, 75(4), 136-154.

McAlister, L. (2005). Unleashing potential. Journal of Marketing, 69(4), $16-17$.

McGrath, J. E. (1981). Dilemmatics: the study of research choices and dilemmas. American Behavioral Scientist, 25(2), 170-210.

Mick, D. G. (2006). ACR presidential address: meaning and mattering through transformative consumer research. In C. Pechmann \& L. Price (Eds.), NA - Advances in Consumer Research (Vol. 33, pp. 1-4). Duluth: Association for Consumer Research.

Mick, D. G. (2007). The end(s) of marketing and the neglect of moral responsibility by the American Marketing Association. Journal of Marketing \& Public Policy, 26(2), 289-292.

Mlodinow, L. (2013). How your unconscious mind rules your behavior. Vintage.

Moorman, C. (2016). Celebrating marketing's dirty word. Journal of the Academy of Marketing Science, 44(5), 562-564.

Olson, J. C. (1982). Presidential Address 1981: toward a science of consumer behavior. In A. Mitchell (Ed.), Advances in Consumer Research (Vol. 9, pp. v-x). Ann Abor: Association for Consumer Research.
Pham, M. T. (2013). The seven sins of consumer psychology. Journal of Consumer Psychology, 23(4), 411-423.

Price, L.L. (2004). How to create, play with and nurture your ideas. Ph.D. Project Conference, October. Boston, MA.

Price, L.L. (2014). 2014 ACR presidential address: obliquity, wonderment and the grand adventure of doing consumer research. In J. Cotte \& S. Wood (Eds.), NA - Advances in Consumer Research (Vol. 42, pp. 1-5). Duluth: Association for Consumer Research.

Raju, J. S. (2005). Revitalizing the role of marketing in business organizations: what can poor academics do to help? Journal of Marketing, 69(4), 17-19.

Rapp, J. M., \& Hill, R. P. (2015). Lordy, lordy, look who's 40!” The Journal of Consumer Research reaches a milestone. Journal of Consumer Research, 42(1), 19-29.

Reibstein, D. J., Day, G., \& Wind, J. (2009). Is marketing academia losing its way? Journal of Marketing, 73(4), 1-3.

Ringold, D. J., \& Weitz, B. (2007). The American Marketing Association definition of marketing: moving from lagging to leading. Journal of Marketing \& Public Policy, 26(2), 251-260.

Russ, S. W. (2014). Pretend play in childhood: Foundation of adult creativity. Washington: American Psychological Association.

Russ, S. W., \& Zyga, O. (2016). Imaginative play. In J. C. Kaufman \& J. Baer (Eds.), Creativity and reason in cognitive development (2nd ed., pp. 52-71). Cambridge: Cambridge University Press.

Sheth, J. N., \& Sisodia, R. S. (2005). Does marketing need reform? Journal of Marketing, 69(4), 10-12.

Sheth, J. N., \& Uslay, C. (2007). Implications of the revised definition of marketing: from exchange to value creation. Journal of Marketing \& Public Policy, 26(2), 302-307.

Shultz, C. J., II. (2007). Marketing as constructive engagement. Journal of Marketing \& Public Policy, 26(2), 293-301.

Staelin, R. (2005a). Influencing the practice through big ideas. Journal of Marketing, 69(4), 21-22.

Staelin, R. (2005b). Era III and IV: my reflections. Journal of Public Policy \& Marketing, 24(1), 146-149.

St-Louis, A. C., \& Vallerand, R. J. (2015). A successful creative process: the role of passion and emotions. Creativity Research Journal, 27(2), 175-187.

Torrance, E. P. (1983). The importance of falling in love with "something." Creative Child and Adult Quarterly, 8(2), 72-78.

Webster, F. E., Jr. (2005). Back to the future: integrating marketing as tactics, strategy, and organizational culture. Journal of Marketing, $4(69), 10-12$.

Wilkie, W. R. (2005). Needed: a larger sense of marketing and scholarship. Journal of Marketing, 69(4), 8-10.

Wilkie, W. R., \& Moore, E. S. (1999). Marketing's contribution to society. Journal of Marketing, 63, 198-218.

Wilkie, W. R., \& Moore, E. S. (2003). Scholarly research in marketing: exploring the '4 eras' of thought development. Journal of Public Policy \& Marketing, 22(2), 116-146.

Wilkie, W. R., \& Moore, E. S. (2007). What does the definition of marketing tell us about ourselves? Journal of Marketing \& Public Policy, 26(2), 269-276.

Winer, R. (2016). Marketing silos. Plenary talk at AMA-Sheth Foundation Doctoral Consortium, University of Notre Dame, June 9.

Yadav, M. S. (2010). The decline of conceptual articles and implications for knowledge development. Journal of Marketing, 74(1), 1-19.

Zaltman, G. (1983). 1983 Presidential Address. In R.P. Bagozzi \& A. Tybout (Eds.) Advances in Consumer Research, (Vol. 10, p. 1-5). Ann Arbor: Association for Consumer Research.

Zaltman, G. (1991). Fellow's award speech: one mega and seven basic principles for consumer research. In R. H. Holman \& M. R. Solomon (Eds.), NA-Advances in Consumer Research (Vol. 18, pp. 8-13). Provo: Association for Consumer Research. 
Zaltman, G. (1997). Rethinking market research: putting people back in. Journal of Marketing Research, 34, 424-437.

Zaltman, G. (2000). Consumer researchers: take a hike! Journal of Consumer Research, 26(4), 423-428.

Zaltman, G. (2003). How customers think. Boston: Harvard Business Press.

Zaltman, G. (2011). Lessons learned during a career. In N. Maholtra (Ed.), Review of Marketing Research: Special Issue - Marketing Legends (Vol. 8, pp. 317-343). Bingley: Emerald Group Publishing Limited.
Zaltman, G. (2016). Marketing's forthcoming age of imagination. AMS Review, 6(3-4) doi;10.1007/s13162-016-0082-3

Zaltman, G., \& Coulter, R. H. (1995). Seeing the voice of the customer: metaphor-based advertising research. Journal of Advertising Research, 35, 35-51.

Zaltman, G., \& Zaltman, L. H. (2008). Marketing metaphoria: what deep metaphors reveal about consumers' lives. Boston: Harvard Business Press.

Zaltman, G., LeMasters, K., \& Heffring, M. (1982). Theory construction in marketing: some thoughts on thinking. New York: John Wiley and Sons. 